\title{
A note on the pattern of feed intake in pigs fed Jerusalem artichoke (Helianthus tuberosus L.)
}

\author{
J. Ly, M. Macias, Vilda Figueroa and J.L. Piloto
}

\author{
Sivine Research Institute \\ PO Box I. Punta Brava. \\ La Habana, Cuba
}

(Received II July 1994; accepted 14 September 1994)

\begin{abstract}
An experiment was conducted with 12 pigs of approximately $25 \mathrm{~kg}$ body weight. The animals were alloted to two experimantal groups where the energy source was either maize meal or raw, fresh tubers of Jerusalem artichoke ( Helianthus tuberosus L.). The pattern of fecd intake was measured for 4 bours following the supply of the meal to the animals in the morning. It was observed that the time the animals spent eating was shorter $(P \leqslant 0.05)$ with maize than with Jerusalem artichoke. The rate of eating was significantly different $(P \leqslant 0.001)$ in pigs fed maize or Jerusalem artichoke on a fresh weight basis ( 23.7 or $43.8 \mathrm{~g}$ fresh feed/min) but was almost equal on a dry weight basis (21.7 or 18.7 g dry feed/ $\mathrm{min}$ ) and therefore feed intake in both ('resh and dry bases was the same for both treatments (1178 or $1142 \mathrm{~g} \mathrm{DM} / \mathrm{pig}$ ). We suggest that pigs modify their patlern of feed intake by increasing meal frequency when high amounts of Jerusalem artichoke are offered as raw, fresh tubers. thus tending to keep the icvel of energy consumption constant.
\end{abstract}

KFY WORDS: pigs, Jerusalem artichoke, pattern of feed intake

\section{INTRODUCTION}

Biological harvest together with supplying an appropriate supplement of protein, vitamins and minerals has been the normal method of feeding Jerusalem artichoke to pigs generally kept in a free range environment. This feeding method is currently being utilized elsewhere (see for example Cañas, 1990; Jost, 1992) since both the fast decomposition of fresh tubers after harvesting and the significant difficulties in dehydrating the Jerusalem artichoke are constraints that have not been overcome as yet. 
When tubers are offered on a raw, fresh basis to confined pigs, it has been observed that the animals spend a long time chewing and swallowing them (Piloto, unpublished data, 1992). However, there are no references to previous works describing this phenomenon in pigs fed Jerusalem artichoke which could explain to what extent the animals may compensate the intake of a bulky feed by modifying their pattern of feed intake.

\section{MATERIAL AND METHODS}

Twelve castrated male pigs of approximately $25 \mathrm{~kg}$ body weight were alloted in a completely randomized design to two treatments where the energy source was cither maize meal or raw, fresh tubers of Jerusalem artichoke. The animals were adapted to eat either the maize meal mixed with soyabean oil meal and the vitamin and mineral supplements in a single meal at $9: 00 \mathrm{am}$ or the same protein, vitamin and mineral supplement first, and immediately after the Jerusalem artichoke. The amount of feed supplied to the animals in shown in Table 1.

The pattern of feed intake was studied for four hours after offering the feed at 9:00 am, following an adaptation period of 28 days. The method used was that of Faliu and Griess (1969) as described by Ly and Castro (1984), and consisted of the continuous recording of the prandial activity of the pigs during the selected observation period. At the end of the first four hours, the remainders of the feed supplied were weighed.

TABLE 1

Composition of the diets

\begin{tabular}{cc} 
& Diets \\
\hline $\begin{array}{c}\text { maise } \\
\text { meal }\end{array}$ & Jerusalem \\
\end{tabular}

Fresh basis, $\mathrm{g}$

Maize meal

Jerusalem artichoke tubers

Soyabean oil meal

$\mathrm{CaHPO}_{4} \cdot 2 \mathrm{H}_{2} \mathrm{O}$

$\mathrm{NaCl}$

Vitamine and trace elements

$\begin{array}{rr}1330.6 & - \\ - & 5780.6 \\ 402.9 & 402.9 \\ 24.6 & 24.6 \\ 4.5 & 4.5 \\ 11.3 & 11.3\end{array}$

Dry basis, $\mathrm{g} / \mathrm{kg}$

Maize meal

Jerusalem artichoke tubers

736.5

Soyabean oil meal

223.1

736.5

Vitamins and minerals

40.4 


\section{RESULTS AND DISCUSSION}

The ingestion frequency of the rations offered was quite different between treatments (Figure 1). It was evident that the animals fed maize concluded their prandial activity about $70 \mathrm{~min}$ after the initiation of feeding. It was observed that when the pigs consumed the Jerusalem artichoke there appeared to be three peaks of consumption of the diet: the first during the first prandial hour and the

\section{Animals eating}
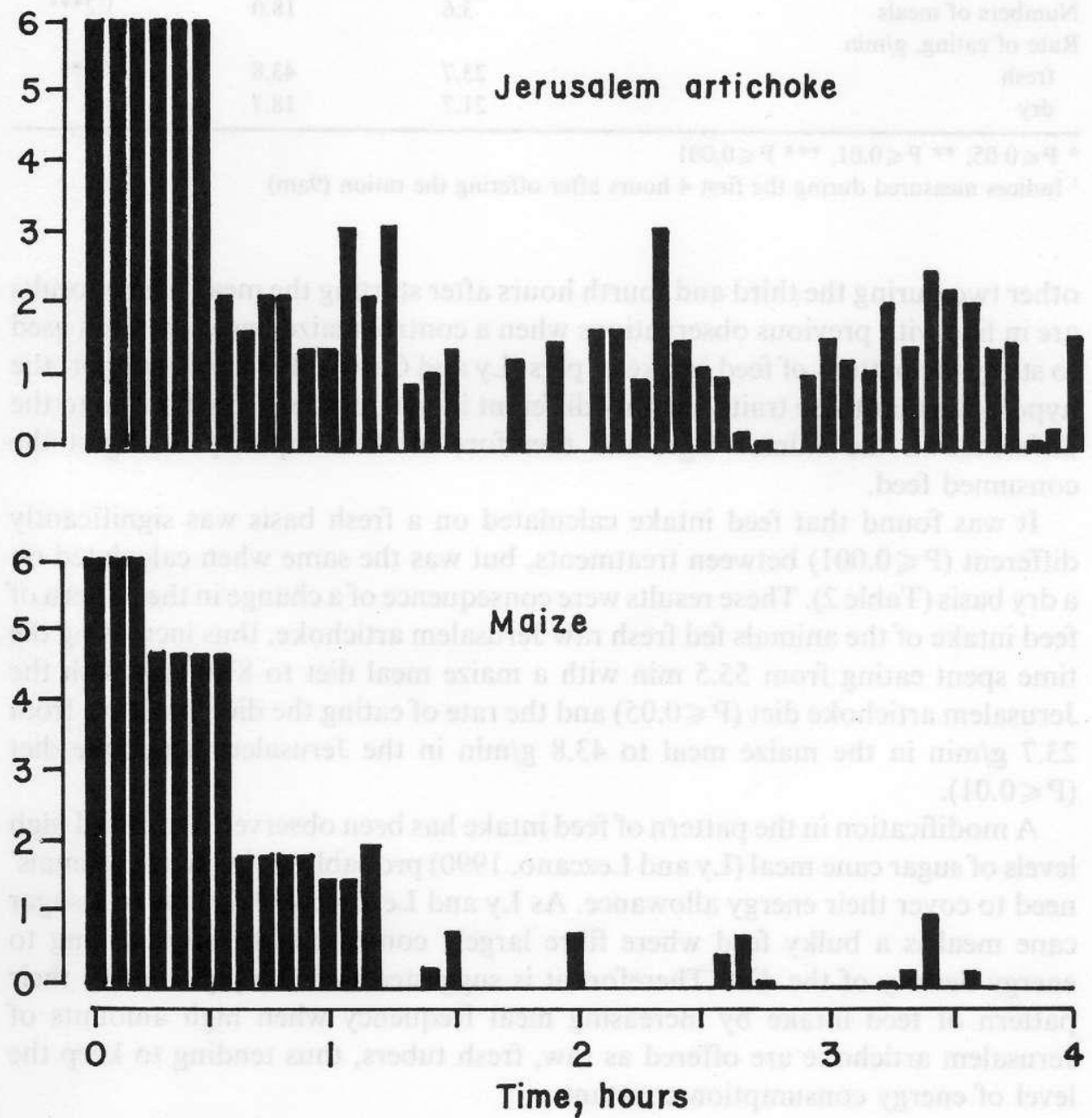

Figure 1. Frequency of ingestion of maize or Jerusalem artichoke diets in the pig. Each vertical bar represents an interval of $5 \mathrm{~min}$ 
TABI.E 2

Pattern of feed intake of pigs given maize meal or Jerusalem artichoke fresh tubers

\begin{tabular}{|c|c|c|c|}
\hline \multirow[b]{2}{*}{ Indices' } & \multicolumn{3}{|c|}{ Diets } \\
\hline & $\begin{array}{c}\text { maize } \\
\text { meal }\end{array}$ & $\begin{array}{l}\text { Jerusalem } \\
\text { artichoke tubers }\end{array}$ & $\mathrm{SE}$ \\
\hline \multicolumn{4}{|l|}{ Feed intake, $g$} \\
\hline fresh basis & 1288 & 3600 & $185^{* * *}$ \\
\hline dry basis & 1178 & 1142 & 152 \\
\hline Eating time, min & 55.5 & 86.0 & $9.9^{*}$ \\
\hline Numbers of meals & 3.6 & 18.0 & $1.2 * * *$ \\
\hline \multicolumn{4}{|l|}{ Rate of eating, $\mathrm{g} / \mathrm{min}$} \\
\hline fresh & 23.7 & 43.8 & $4.3^{* *}$ \\
\hline dry & 21.7 & 18.7 & 3.1 \\
\hline
\end{tabular}

* $\mathrm{P} \leqslant 0.05 ; * * \mathrm{P} \leqslant 0.01, * * * \mathrm{P} \leqslant 0.001$

Indices measured during the first 4 hours after oftering the ration ( $9 \mathrm{an})$

other two during the third and fourth hours after starting the meal. These results are in line with previous observations when a control maize-based diet was used to study the pattern of feed intake of pigs (Ly and Castro, 1984) and support the hypothesis that these traits are only different in magnitude, probably due to the difference in the animals age, and therefore in their capacity to digest the consumed feed.

It was found that feed intake calculated on a fresh basis was significantly different $(P \leqslant 0.001)$ between treatments, but was the same when calculated on a dry basis (Table 2). These results were consequence of a change in the pattern of feed intake of the animals fed fresh raw Jcrusalem artichoke, thus increasing the time spent eating from $55.5 \mathrm{~min}$ with a maizc meal diet to $87.0 \mathrm{~min}$ with the Jerusalem artichoke dict $(P \leqslant 0.05)$ and the rate of eating the diet in natura from $23.7 \mathrm{~g} / \mathrm{min}$ in the maize meal to $43.8 \mathrm{~g} / \mathrm{min}$ in the Jerusalem artichoke diet $(P \leqslant 0.01)$.

A modification in the pattern of feed intake has been observed in pigs fed high levels of sugar cane meal (Ly and Lezcano, 1990) probably owing to the animals' need to cover their energy allowance. As Ly and Lezcano (1990) claimed, sugar cane meal is a bulky feed where fibre largely contributes to disminishing to energy density of the diet. Therefore it is suggested that the pigs modify their pattern of feed intake by increasing meal frequency when high amounts of Jerusalem artichoke are offered as raw, fresh tubers, thus tending to keep the level of energy consumption constant. 


\section{REFERENCES}

Cañas R., 1990. Uso del topinambur (Helianthus tuberosus) y ensilije de pescado en la producción porcina extensiva. In: Taller Reg. FAO. Utilizacion de Recursos Alimentarios en la Produccion Porcina de América Latina y el Caribe. La Ilabana, pp 10

Faliu L., Griess D., 1969. Le comportement alimentaire du porc charcutier. J. Rech. Porcine France, Paris, 1, 61-65

Jost M., 1992. Paturage des porcs: topinambours et prairies artificielles. Rev. Suisse Agric. 24 (3), 173

Ly J., Castro M., 1984. Pig fattening with sugar cane molasses. 1. Performance traits and consumption pattern. Cuban J. Agric. Sci. 18, 35-42

Ly J., Lezcano P., 1990. Patrón de consumo de ecrdos alimentados con cana de azucar cnriquecida por fermentación en fase solida (Saccharina). II. Sem. Internac. Azucar y Deriv. Cand, La Habana 1. 238-241

Mróz. Z., Partridge I.F., Mitchell G.. Keal H.D., 1986. The effect of oat hulis. added to the basal ration for pregnant sows, on reproductive performance, apparent digestibility, rate of passage and plasma parameters. J. Sci. Food Agric. 37, 239-247

\section{STRESZCZENIE}

\section{Pobieranie paszy przez świnic żywione kłębami bulwy}

Dwanaście wieprzków. o masic ciała około $25 \mathrm{~kg}$, podzielono na dwie grupy żywieniowe, w których podstawowym źródlem energii była mączka z kukurydzy lub surowe klęby bulwy. Pobieranie paszy przez. zwierzęta rejestrowano prre 4 godziny od ich podania. Czas zjadania dawki z kukurydzą byl krótszy $(P \leqslant 0.05)$ niż $z$ bulwą. Tempo pobierania paszy istotnie $(P \leqslant 0.01)$ rózniło się między świniami obydwóch grup: w przeliczeniu na świeżą masę wynosiło $23.7 \mathrm{i} 43.8 \mathrm{~g} / \mathrm{min}$, w przeliczeniu na suchą masę $21.7 \mathrm{i} 18.7 \mathrm{~g} / \mathrm{min}$, odpowiednio præyy sk armianiu dawki z kukurydzą lub bulwą. Całkowite pobranic suchej masy było podobne i wynosiło odpowiednio 1178 i $1142 \mathrm{~g} /$ rwierzec. Wyniki wskazują, że świnie modyfikują pobieranic paszy przez zwiększenie częstotljwości posiłków, dla utrzymania stałego poziomu energii, przy skarmianiu świeżych klębów bulwy. 